groups on specific subjects. They should also send staff to train community leaders in their respective homelands, with the objective of increasing public participation there. Training in areas which lend themselves to regionally or internationally applicable methods should be developed by the UN agencies. Areas in this category include assessment, monitoring, and evaluation, of desertification, economics of development of arid lands, common techniques in plant and animal husbandry, and land-use surveys and capability maps etc.

\section{Regional Programmes}

Scientific and technological issues related to desertification and the various facets of its problem often transcend national political boundaries. These issues may need to be examined (monitored and assessed), and to be resolved within regional (transboundary) extents. Resources in arid lands may be regionally shared (e.g. ground-water aquifers), or may be best managed regionally (e.g. transnational management of rangeland and livestock resources). Certain aspects of research and training would be unduly expensive if carried at a national level, and would be more efficiently (cost-effectively) carried out at a regional level.

It seems essential at least that each region should have a multipurpose institute which trains technicians in resource assessment and management for dryland areas. Such an institute should have government support and recognition, with an interdisciplinary focus - and with a practical methodology related to realities of the participating nations. The regional centres would be foci for developing and distributing new ideas, and for coordinating monitoring as well as training programmes and short courses, while also running pilot projects. The national effort would then focus on adapting this to specific physical and socio-political conditions. National components may receive technical and financial support through bilateral sources, private foundations, and nongovernmental institutions.

The approach of having a series of national institutions of research and training, constituting a regional network, seems feasible. It could provide for mutual support and more efficient use of available resources than at present obtains, and would enable research projects to extend beyond national boundaries-indeed right up to the natural boundaries of the problems themselves. Criteria for selection of participating national bodies need to be flexible.

Modalities for cooperation and coordination at national and regional levels will ensure the most efficient use of available resources of manpower, research and training facilities, and funds. Dimensions of regional networks need to be flexible, so as to avoid political and historical difficulties and to address ecological limits. Existing divisions include the present United Nations regions of the Economic Commissions. But sub-regions may be recognized-for instance, the continent of Africa may be subdivided into North Africa, The Sudano-Sahel, and Africa South of the Equator.

It would also be useful to extend networks from the developing countries into the industrialized regions. Joint activities, partnership arrangements for research, training, information, and dissemination and supply of equipment, should be organized.

\section{International Programme}

Regional networks should be linked together in a form of international or global network, the objective being to coordinate their work and avoid wasteful duplication. This should aim at establishing an information exchange system and ensure maximum benefits from it. Such an international network would need a sponsor, whose function would be to ensure coordinated planning and implementation of activities and the development of network linkages. The sponsor should also provide resources to support the desired programme development.

As is known, programmes and projects carried out by, or under the aegis of, the United Nations agencies and bodies, include extensive activities that relate to control of desertification and to development of natural resources in arid and semi-arid lands. These activities include several programmes and projects of research and training. Thus the aim is to develop an international Programme of coordinated research and training activities within the framework of the Plan of Action to Combat Desertification (see above), which should in particular include all relevant activities of the whole UN system. Such an international programme should: (a) be composed of several specific programmes of research and training at various levels, (b) have the participation of national and regional institutions in its field of action, and (c) function through a system of regional networks incorporated in a global network.

Mostafa K. Tolba, Executive Director United Nations Environment Programme P.O. Box 30552

Nairobi

Kenya.

\title{
An Urgent Call to All Science Teachers and Adherents: The World Campaign for The Biosphere
}

In 1972, a United Nations Conference on the Human Environment was held in Stockholm, Sweden, which publicized mounting concern (e.g. Pauling et al., 1982). Such concern was over the rapid growth of our world's human population, continued military expenditures for nuclear weapons, the depletion of our world's resources, and other environmental problems. At the end of this Conference, twenty-nine principles were developed and over one hundred recommendations were formed in the hope that world powers would begin efforts to cease the continued degradation of our Biosphere.

It has now been more than a decade since that Conference. After such a period, what has been the outcome of these principles and recommendations? According to the Foundation for Environmental Con-
'To date, concerned actions to safeguard The Biosphere have been reactive rather than preventive in intent, and on scales pathetically below those on which problems have been spreading. As a result, many of these problems have become far more serious and less controllable than hitherto, while new ones continue to emerge. This lack of global organization, the character of which is marked by failure in interaction, is unworthy of free-minded people and unfair to Nature.' The Foundation's analysis of the status of our environment is similar to the major findings and conclusions of The Global 2000 Report to the President (1980), which was 
compiled and written during the Carter Administration. This report states that, if present trends continue, the world will become more and more overcrowded, more and more polluted, and less and less stable ecologically. This Report does not make predictions into the future; instead, it depicts conditions that are likely to develop if there are no changes in public policies, institutions, or rates of technological advance, and if there are no wars or other major disruptions of the environment. Generally, the conclusions drawn from this report indicate a very dismal outlook for a large proportion of the world's population with regard to adequate food and other basic needs. This report states:

'Barring revolutionary advances in technology, life for most people on earth will be more precarious in 2000 than it is now - unless the nations of the world act decisively to alter current trends.'

Because our future welfare and the welfare of all living things appears to be in serious jeopardy, a group of environmentalists proclaimed-on 5 June 1982, which was Environment Day and the tenth anniversary of the United Nations Conference on the Human Environment-The World Campaign for The Biosphere. The goals of the Campaign include:

1. To develop and foster on a continuing basis, educational programmes designed to make the concept of Our Biosphere personally meaningful to all people;

2. To improve the scientific understanding of the design and operation of The Biosphere;

3. To develop ways to safeguard The Biosphere;

4. To encourage the reduction of the physical and spiritual harm that is inflicted on all humans and also Nature by failing to accommodate to Our Biosphere's needs and ways.

Throughout the United States and Canada, significant components of environmental education have been integrated into the K-12 science curriculum. Some joint efforts of interdisciplinary instruction have also taken place between science teachers, social studies teachers, and teachers of other disciplines. However, I believe that greater and greater efforts need to be directed at analysing environmental problems and proposing realistic solutions to these problems. I feel that science teachers should re-examine their science curriculum and make a careful appraisal of whether their science programme meets the objectives of the World Campaign's proclamation. For example, are topics concerning human population-growth, the possible outcomes of a nuclear war, the security of future energy supplies, the consequences of deforestation and devegetation, the implications of continued use of insecticides, and effects of atmospheric pollutants on Our Biosphere, currently being addressed in science? Are students involved in activities that allow them to investigate their environment, analyse specific environmental problems, and propose realistic solutions and alternatives to these problems?

The World Campaign project is a challenge facing all of us who really care about our world's future (Polunin, 1982), but science teachers have a special opportunity to meet this challenge. They are in a unique position to make young people aware of our dependence on the continued health of The Biosphere and of the fragile interrelationship that exists between it and ourselves. Let them therefore join with their environmentalist and social studies colleagues to make a concerted effort to achieve the goals of the World Campaign, which can and should play an integral role in their future and that of their students.

\section{REFERENCES}

The Foundation for Environmental CONSERvation (1982). Declaration: The World Campaign for The Biosphere. Environmental Conservation, 9(2), pp. 91-2.

The Global 2000 RePort to THE PRESIDENT (1980). Entering the Twenty-first Century (Volume One). Superintendent of Documents, US Government Printing Office, Washington, DC 20402, USA: ix + 47 pp., appendix, illustr.

Pauling, L., Benavides, F., Wahlen, F.T., Kassas, M., Vohra, B.B. \& KNOX, G.A. (1982). Open Letter: To all who Should be Concerned. Environmental Conservation, 9(2), pp. 89-90.

Polunin, N. (1982). Our global environment and the World Campaign for The Biosphere. Environmental Conservation, 9(2), pp. 115-21, 2 figs.

CHARLES R. BARMAN
Associate Professor of Science Education
Indiana University at Kokomo
2300 South Washington Street
Kokomo
Indiana 46902
USA.
Associate Professor of Science Education Indiana University at Kokomo 2300 South Washington Street

Indiana 46902

USA.

\section{Acid Rain Information Clearinghouse}

The Acid Rain Information Clearinghouse (ARIC) is now offering its services to scientists, research workers, policy makers, attorneys, environmentalists, business people, sportsmen, and others concerned with the phenomena of acidic deposition.

ARIC is perhaps the only operation conducting periodic updating of the acid precipitation informationbase in North America, including searches for state and agency reports and any fugitive sources. Clearinghouse resources include on-call reference and referral service, computerized literature and information searching, and a core reference collection. ARIC's activities are designed to promote an interdisciplinary awareness of pertinent research in the sciences and engineering, and of policymaking and the activities of government, industry, and public interest-groups.

ARIC publishes the Acid Precipitation Digest, a monthly bulletin with annotated citations and 'capsule' summaries of news items, peer-reviewed literature, periodical articles, conference proceedings, technical reports, and books. The Digest also contains a calendar of upcoming conferences and other pertinent events.

Located in Rochester, New York, ARIC is a project of the Center for Environmental Information, Inc. (CEI), which was established in 1974. The Center is a private, non-profit educational organization which, as a matter of policy, does not take positions on issues. For further information on the full range of ARIC services, contact Frederick W. Stoss, Manager of Information Services, Center for Environmental Information, Inc., at the address given below, or telephone (716) 546-3796.

ELIZABETH THORNDIKE, Executive Director
Acid Rain Information Clearinghouse
Center for Environmental Information, Inc.
33 South Washington Street
Rochester
NY 14608, USA.

ELIZABETH THORNDIKE, Executive Director Acid Rain Information Clearinghouse 33 South Washington Street

NY 14608, USA. 